This article belongs to the Special Issue Public sector Innovation Conceptual and Methodological Implications

Guest Editors: Ann Karin Tennås Holmen (UiS), Maria Røhnebæk (INN)

\title{
Conceptualising public sector innovation: Introducing the lens of the epistemological, pragmatic and normative dimensions
}

\author{
Luise Li Langergaard* \\ Department of People and Technology \\ Roskilde University \\ Email: luiseli@ruc.dk
}

*corresponding author

\begin{abstract}
Innovation is a relatively new concept in the public sector, and there is currently no broad agreement regarding how to understand and conceptualise it. This article assumes that a central role for research is to critically scrutinise and discuss what research does-or could do-when applying the concept of public sector innovation, especially because innovation has become a powerful organising metaphor for policy and practice. The article initiates a meta-conceptual inquiry and discussion of public sector innovation as a research concept, suggesting a method of conceptual clarification for future research by breaking the concept down into different dimensions. Methodologically, the article conducts a meta-conceptual analysis and inquiry into research positions and discussions in public sector innovation, thus reflecting the academic activity/enterprise of conceptualising. By discussing selected literature from the public sector innovation field, three conceptual dimensions emerge:

epistemological, pragmatic and normative dimensions. These dimensions refer to questions about what kind of knowledge the concept of public sector innovation represents, what its pragmatic or practical implications are and which normative or value dimensions the concept implies. Finally, the concluding discussion highlights questions for research(ers) to address in future reflections on the conceptualisation of public sector innovation.
\end{abstract}


Keywords: Public sector innovation, conceptualisation, innovation theory, public value, network governance

\section{Introduction}

Innovation has become a core concept pushing towards change and development in the public sector and 'is increasingly viewed as an appropriate and intelligent answer to some of the key governance challenges of our time' (Agger et al., 2015, p. 3). It has become imperative for public sectors to demonstrate that they are innovative and adaptive to the new innovation agenda. Indeed, innovation has been promoted as a path towards more efficient, effective and responsive public services, and it has been suggested as a solution to various social and political challenges (Albury, 2005;

Damanpour \& Schneider, 2009; De Vries et al., 2016; Hartley \& Moore, 2008; Kattel et al., 2014; King \& Martinelli, 2005, p. 1; Moore, 2005, p. 44; Mulgan \& Albury, 2003), such as ageing populations, ambitious goals to reach climate targets and currently a number of challenges emerging under the Covid-19 pandemic (OPSI, 2020). Innovation is said to equip the public sector to better deal with wicked problems that are too complex to be dealt with merely by known solutions models or by increasing the funding (Chen et al., 2020; Torfing, 2019). However, innovation is also a relatively new concept in the public sector, and currently, there is no widely accepted definition of what counts as innovation in this area (Pollitt, 2011). As Pollitt (2011) points out, innovation is not a concrete object; it is a concept, or rather a word that labels a concept. This applies not only to public sector innovation, but also to the concept of innovation more generally. The concept of innovation itself has a long history and has seen a change in meaning over time, from being associated with 'disorder, anarchy, confusion and disillusion' (Godin, 2015, p. 1) to today, where the term has much more positive connotations (Godin, 2008, 2015). Despite its long history, there is no consensus on what innovation means more generally, especially not in the public sector context (Pollitt, 2011). Some researchers stress the lack of theorisation and theoretical frameworks in public sector innovation (Chen et al., 2020; De Vries et al., 2014), which calls for further inquiry and discussion at the meta-theoretical and meta-conceptual levels.

Therefore, the current article attempts to critically scrutinise and discuss what research does-or could do-when working with the concept of public sector 
innovation, especially because this concept has become a powerful organising metaphor for policy and practice. Concepts and academic work have implications not only in the world of academia, but also for practice and policy. Thus, it matters what we understand as innovation in the public sector and how we address it conceptually and practically. Public sector innovation is a concept stretching between academia, policy and practice, but it also involves conceptual and theoretical plurality. The research dialogues on public sector innovation suffer from disintegration, being an interdisciplinary research field where researchers have different understandings of the same concept. There are various definitions and implicit understandings of innovation, but there is little dialogue on how and why it should be defined or conceptualised in certain ways (there are exceptions to this, e.g., Osborne and Brown (2011) and Hartley (2014), which will be included in the analysis). Therefore, the criteria for what a 'good', 'appropriate' or 'relevant' concept could be are rarely discussed.

The present article aims to explore and unfold the concept of public sector innovation in a way that enables a meta-conceptual reflection and shared dialogue on the enterprise of conducting research on public sector innovation and on why we should conceptualise it in certain ways. This inquiry into the public sector innovation concept is relevant because concepts not only reflect reality in a descriptive way but are also performative and have implications for practice and in the ways they constitute the object of research that they refer to (Callon, 2010). Thus, it matters how we conceptualise. The analytical entry point of this article is to ask the following: Which questions can the concept of public sector innovation be an answer to? What does this imply in terms of knowledge, practical interests and value orientations?

More specifically, these questions lead to three specific dimensions of conceptualising: epistemological, pragmatic and normative dimensions. These three dimensions were selected because they underline some of the differences in academic concepts of public sector innovation, namely the role of the concept in knowledge production, researchers' interest in exploring and implementing innovation (a pragmatic, practical dimension) and the possible association of innovation with value creation, improvement or ideas about the 'good' society (a normative dimension). The current article unfolds these dimensions through a discussion of the selected conceptualisations of and debates on public sector innovation to understand how researchers apply and 
work with the concept. The ambition is not to provide a comprehensive review of the field, but to discuss the selected contributions that illuminate some of the conceptual differences and points of intersection. The present article contributes to academic debates by focusing not only on the concept of public sector innovation, but also on the academic activity of conceptualising to enable reflection and dialogue on what researchers do when they develop the concept of public sector innovation.

The present article is structured as follows: the next section examines why innovation is seen as a relevant and timely concept. Then, the methodological approach is presented, followed by the analysis and discussion of the different dimensions of conceptualisation. Finally, there is a discussion of the ways for research to move forward in conceptualising, which is done by specifying some guiding questions.

\section{Why should the public sector be innovative?}

The following section addresses the emergence of the innovation concept in relation to the public sector and provides some context for the analysis. This is relevant for understanding what this concept is supposed to be an answer to (practically or academically). As mentioned in the introduction, the innovation concept is still relatively new in the public sector, and its emergence and development is a relevant context for understanding current conceptualisations in the field. Over time, change and development within the public sector and the services provided by this sector have been understood and conceptualised in different ways following paradigmatic changes in research, policy and practices in the public sector (Langergaard, 2011; Hartley, 2005). The Public Administration paradigm has focused on policy implementation (Sannerstedt, 2003) and on large-scale changes and improvements initiated by politicians developing new policy frameworks and changes in legislation (Hartley, 2005, pp. 29-30). The introduction of New Public Management in the 1980s and 1990s consolidated the idea that the public sector should continuously develop and renew itself, which led to the introduction of the concept and practice of innovation in the public sector (Buchheim et al., 2020; Sørensen \& Torfing, 2011a). In the meantime, the overall paradigmatic framework of public administration research has developed towards a greater dominance of Networked Governance, now containing a broader variety of perspectives that go beyond New Public 
Management and an unreflective adoption of the concept of private sector innovation. Today, we can see a stronger emphasis on collaboration, interorganisational networks and coproduction (Bommert, 2010; Hartley, 2005; Sørensen \& Torfing, 2011b; Torfing, 2019), and here, innovation has also recently been included in the growing body of research specifically focusing on value creation and public value (Benington, 2011; Benington \& Moore, 2011; Crosby et al., 2017).

The introduction of innovation as a term for public sector change and development has been accompanied by certain narratives about why we need public sector innovation; these present the idea that contemporary societal challenges call for innovative solutions and organisations. Innovation is presented as a necessity if the public sector is to meet current and future societal challenges related to, for example, changing demographics and citizens' increasing demands for quality, flexibility and control of public services (Bason, 2010; De Vries et al., 2014; Fuglsang \& Rønning, 2014; Moltesen \& Dahlerup, 2008; Sørensen \& Torfing, 2011a). Innovation is portrayed as a cost-saving alternative to blind, across-the-board cuts and as helping address wicked problems that cannot be solved by standard solutions or by increasing expenditures alone (Chen et al., 2020; Torfing, 2019). From an organisational perspective, innovation is thought to enhance the problemsolving capacity of governmental organisations (De Vries et al., 2016) and is considered a source of organisational change, growth and effectiveness (Damanpour \& Schneider, 2009). Furthermore, innovation is said to be important because of the dynamic, volatile conditions that make societies change their requirements of government, public organisations and public managers; however, organisations still need to adapt to such unstable conditions (Buchheim et al., 2020; Hartley, 2011). At first glance, innovation may appear very promising and is portrayed as a general solution, or a panacea (Kattel et al., 2014). It can even be said to be a 'hurrah' word (Langergaard, 2011) or a magic concept (Pollitt, 2010: Pollitt \& Hupe, 2017). These arguments for why the public sector should be innovative indicate that there is a normative dimension to the concept and that it might be considered desirable, but also that researchers are interested in innovation because it can help them understand how to solve problems or make more general improvements. The question, then, is how researchers can address such questions in relation to public sector innovation. In this context, the current 
article proposes a meta-conceptual approach to the public sector innovation concept and to the act of conceptualisation, as discussed below.

\section{Methodological approach}

Methodologically, the present article deploys a meta-conceptual analysis and inquiries into discussions on the concept of innovation in the field of public sector research; it reflects on the academic activity of conceptualising and theorising by inquiring into the activity of conceptualising, just as philosophy/theory of science is a reflection on the criteria for conducting science and producing knowledge (Langergaard et al., 2006). Such questions are addressed here not as 'isms' but as an inquiry into some of the underlying assumptions about theorising or conceptualising that may not be explicit in the literature. One could see this as a hermeneutic inquiry, or an attempt to understand the approaches to public sector innovation and understand what kinds of questions the concept is supposed to be an answer to.

The meta-conceptual dimensions by which the discussion and analysis are conducted are also found in the philosophy of science discussions about knowledge, practice and values/normativity and here are interpreted specifically in relation to public sector innovation research. Similar discussions can be found in relation to theorising in organisation studies. Through conversations with thinkers in organisation studies, Hansen and Madsen (2019) find that the actual act of theorising becomes elusive and that what one does when theorising is difficult to communicate to others. Similarly, there is little explicit discussion about the act of conceptualising in public sector innovation studies. Because the field seems to be more concerned with the concepts and definitions of public sector innovation than with developing theories of innovation, the present article focuses on conceptualisation, even though the considerations and concerns are closely related to the activity of theorising as well. The word 'concept' originates from 'concipere', meaning to conceive, to take in and hold or to grasp (Etymonline.com, n.d.). This indicates an activity, an act of making graspable. It is this active role that is assumed here.

The aim is not to provide a comprehensive review of the field or include all possible positions. The selected literature encompasses literature reviews that provide some form of overview or state-of-the-art look at the field. Further, 
specific contributions that engage in reflections and discussions about how to conceptualise innovation are included as examples to unfold and exemplify the conceptual dimensions. The included literature addresses public sector innovation mainly from a public administration perspective, discussing innovation in relation to the public sector in general rather than from the perspective of specific sectors or professions. Some literature from the expanding field of public value is also included, mainly as a perspective on the normative dimension, but because this literature is vast, it will not be elaborately treated in its own right.

Before moving on to the analysis, I present a few remarks on the three dimensions. Epistemology relates to theories of knowledge (Audi, 1998). In relation to public sector innovation, Pollitt (2011) sees social science in general and public administration in particular as ridden with epistemological differences, ranging from nomothetic approaches to more ideographic ones, which he also finds in public sector innovation research. Nomothetic approaches strive to discover the underlying (causal) mechanisms and laws, often with the aim to control and predict. Ideographic approaches work more along a hermeneutic or interpretative line, with a stronger emphasis on the subtleties of context and interpretation (Pollitt, 2011). The lack of paradigmatic consensus among innovation researchers complicates the process of theory building (Buchheim et al., 2020) and is also reflected in conceptualising. Not all approaches in the field are equally explicit about their position, but further inquiry may elucidate the differences to be discussed, pointing out pathways for future research. The practical or pragmatic implications of 'innovation', here relating to the argument for why we need such a concept, also differ. Pragmatism denotes a range of positions in the philosophy of science, which also represent various meanings and epistemological approaches (Goodman, 1995; Haag, 2003). The point here is not to embrace all these pragmatic philosophies, but rather to emphasise the practical dimension as separate: namely the practical implications of using concepts, where the meaning of a concept lies in its use (Haag, 2003). Finally, the analysis examines the normative dimension of innovation concepts in the public sector. This will be approached by exploring how the concepts of public sector innovation rest on implicit or explicit normative assumptions and how they link to improvement and value creation. 


\section{Conceptualising public sector innovation}

The meta-conceptual analysis represents an explicit reflection on the criteria for the concept and what is required of a 'good' or appropriate concept of public sector innovation (see Langergaard 2019 for a similar discussion on the concept of social entrepreneurship). The simple question to begin with is as follows: What do we as researchers want to achieve with the concept? Should a concept, for example, mirror or order empirical reality as accurately as possible, should it work as a 'tool' for management, or should it be a driver for strengthening the democratic and public dimensions of the public sector?

\section{Epistemological dimension}

Epistemology is the theory of knowledge and justification of knowledge. In philosophy, epistemological questions address the notions of truth and the different ways of understanding what knowledge is and can be, as well as what we cannot know about. In the current article, the epistemological dimension concerns the type of knowledge reflected in the concept, for example, if the concept is seen as intended to describe, interpret or explain a certain phenomenon. This involves reflections about the relationship between the concept and phenomenon, such as whether the concept is meant to mirror an empirical phenomenon as accurately as possible. Is it concerned with what is out there, and if so, how is empirical reality thought to relate to the concept? Or is the conceptualisation aimed at understanding in a more hermeneutic sense the intersubjective construction of meaning?

To provide examples of how we can view different epistemological approaches, we can examine Schumpeter's concept of innovation, which aims at explanation and is closely linked to a specific question: How does economic development take place (Schumpeter, 2008)? Schumpeter's theory was developed as a supplement and challenge to the neoclassical economics of his time and their focus on the economy as a static system. The focus on equilibrium, according to Schumpeter, led to difficulties in explaining how economic development was possible (Swedberg, 2006). An example is included because we also see explanatory approaches to public sector innovation in the academic field. Here, they generally occur in connection with a widespread interest in explaining how innovation occurs but often without a broader theoretical framework, as seen in Schumpeter (2008). As Gow (2014) explains, theories use concepts to organise raw material into variables, 
abstract categories concerning causal variables and outcome variables. This is one understanding of what a concept is (or does) and its role in theory that is present in public sector innovation research.

Several review articles identify the dominant research interest as studying how innovation occurs and uncovering its determinants or antecedents (Buchheim et al., 2020; De Vries et al., 2016; Gieske et al., 2016), often expressed in terms of barriers and drivers for innovation (Becheikh et al., 2007; Bekkers et al., 2013). We find arguments for the need for consistent concepts of innovation to develop measuring tools. Chen et al. (2020) suggest a typology and emphasise the operationalisation of innovation types, including potential measures, in more detail (Chen et al., 2020). This indicates an interest in developing the concepts and tools to measure innovation and make statistics, where operationalisation is a central feature of a 'good' or 'appropriate' concept that can enable consistent measurements and general insights about how innovation occurs. In a review of the literature on the barriers to public sector innovation, Cinar et al. (2019) formulate their research questions in general terms, such as what the specific barriers in public sector innovation are, how they can be classified and their interrelationship (Cinar et al., 2019). This indicates that innovation is seen as a general category referring to a certain empirical phenomenon, which can be delimited and identified across various contexts. When public sector innovation is conceptualised in such general ways, there is no concern for contextual factors, such as the specifics of national welfare or political systems, or for the differences between subsections of the public sector, such as a core focus on service provision or authority functions.

We also find other kinds of reflections on why we need to conceptualise in certain ways. Practice-based theoretical understandings of innovation, for example, insist that to understand how development and innovation actually take place in public sector organisations, we need to recognise certain activities as forms of innovation. Bricolage and ad hoc innovation, which are not always planned but can be recognised as innovations a posteriori, are terms for certain types of innovation activities seen in public sector services, which differ in various ways from strategically planned, deliberate and radical changes (Fuglsang \& Sørensen, 2011). Fuglsang and Sørensen (2011) argue that innovation research tends to grasp only the more formalised aspects of innovation and that these more informal, everyday work processes, which entail new ways of solving tasks and dealing with day-to-day challenges, 
should be included in innovation theories. In terms of conceptualising, these reflections show how Fuglsang and Sørensen (2011) seek to develop a concept that reflects reality; certain practices are already taking place that we need a concept for. They argue that innovations can be embedded in organisational practices, despite the actors not referring to the activities as innovation. To capture this, they argue for expanding the concept of innovation to include bricolage. Here, one can identify a descriptive research interest, where concepts are intended to capture and describe some practical reality. Compared with the aims of measuring or finding general insights about barriers and antecedents, this approach seems to call for a greater sensitivity to practice and context and appears to be a more inductive approach, where it is important that the concepts capture features of empirical reality and actual practices. This is a way of conceptualising that aims to describe rather than predict, and this approach does not seem to have a specific instrumental or management agenda.

The above approaches seem less aware of the performative dimensions of a concept and show less interest in the implications for practice and what they may mean for public sector management when it comes to organising them in line with specific concepts of innovation. Concepts also have practical implications, which we can become more aware of when conceptualising.

\section{Pragmatic dimension}

We can also understand the ways of conceptualising as aimed at making the reality that we gain insights into more manageable. We can see the pragmatic (and practice-oriented) dimension of conceptualising regarding what the concept is thought or supposed to do, such as to further the management of innovation processes in public sector organisations. This could also be called an instrumental dimension, and sometimes, this is implied in the abovementioned attempts to uncover the general insights about antecedents, drivers and barriers.

This also implicitly or explicitly lies behind the prevalent interest in incentive structures (Potts \& Kastelle, 2010), determinants or antecedents, drivers and barriers (Becheikh et al., 2007; Bekkers et al., 2013; Buchheim et al., 2020; De Vries et al., 2016; Gieske et al., 2016; Torfing, 2019), which not only teach us how innovation occurs, but also control, manage and attempt to promote innovation in public sector organisations. For example, Cinar et al. (2019) see 
knowledge about the barriers to innovation as an important success factor in innovation management and, thus, are clear about the additional practical (or instrumental) purpose of their pursuit of knowledge and conceptualisation of innovation. This illustrates that the conceptual dimensions are interconnected. Hartley (2014) also suggests 'eight and a half propositions' for how to stimulate public sector innovation to encourage new approaches to innovation among managers, policy makers and academics. Torfing (2019) and Sørensen and Torfing (2011b) argue that multiactor collaboration is a key driver of public sector innovation. Thus, collaborative innovation is promoted as helping make the public sector better at solving certain types of problems, which is the knowledge we wish to acquire. There is also an interest in drivers, and it seems to be assumed that we want more innovation. In this sense, there is also a normative agenda, which we return to below.

When innovation is understood more broadly as a solution, this seems to encourage pragmatic approaches to the concept, where it is thought to be instrumental in fostering certain practices and where innovation research is concerned with how to make innovation happen or how to manage it. If innovation is thought to be a necessity for organisations, the obvious question is how to achieve innovation. All these approaches want to do something with innovation, which is why they are interested in the concept, yet there seem to be two related-but still separate-arguments involved. One is that innovation will make the public sector better at solving its tasks (and innovation can then be a solution to various problems), while the other is that certain features of reality necessitate adaptability. This argument is seen in the literature on public sector innovation, when, for example, innovation is said to be important because of the dynamic, volatile conditions that make societies change their requirements of government, public organisations and public managers, while organisations need to adapt to such unstable conditions (Buchheim et al., 2020; Hartley, 2011). Here, innovation is not so much an explanatory concept but rather a more general and not clearly specified 'tool' used to adapt and survive; however, this reveals little of the direction of change related to innovation. Du Gay and Vikkelsø (2017) emphasise the lost specification of change in organisation theory, meaning that change (and innovation) has become represented as a broad, generic organisational imperative, without specification or connection to particular contexts and organisational purposes. Paulsen (2011) states that such argumentation can become nihilist and simply used to promote change for the sake of change. This leads to discussions 
about another concern regarding the pragmatic dimension when conceptualising innovation: the distinction between innovation and other concepts of change. Osborne and Brown (2011) insist on a distinction between developmental change and innovation as discontinuous change, explicitly arguing that we need two different concepts because the two types of change require different types of management. This clearly focuses on the practical difference between the two concepts (change and innovation). Often, the pragmatic dimension is an underlying concern related to making innovation happen or managing it in certain ways, as exemplified above, because innovation is sometimes considered a solution. However, the questions of the desirability of innovation and its effect as improvement lead us into the normative dimension.

\section{Normative dimension}

The normative dimension addresses the why of public sector innovation, more specifically in relation to its evaluative or value dimension. Normativity can be seen as the common feature of everything that 'ought to be', here distinct from what 'is' (Dancy, 2000). There are different ways of approaching normativity. Moral philosophy and ethics deal with the justification of moral or ethical norms and claims, including claims of morality, etiquette and debates on how these can be justified (Copp, 2001). In public sector innovation, the normative dimension often relates to explicit or implicit assumptions about what the public sector ought to do or be, how innovation relates to that and whether innovation helps improve the public sector (according to values or norms, either assumed or specified).

The normative dimension can also involve assumptions or claims related to the desirability or value of innovation. Pollitt (2011) emphasises that innovation is a fashionable concept with a strongly positive normative undertone, suggesting that innovation is inherently good (Osborne \& Brown, 2011) and defined as leading to improvements (Mulgan \& Albury, 2003, p. 3). The mere assumption that innovation will lead to desirable outcomes but without further specification or justification has been described as a 'pro-innovation bias' (Hartley, 2016) or 'the innovation imperative' (Osborne \& Brown, 2011). From this perspective, innovation is necessarily valuable or effective, hence bring forth an unquestioned need to accelerate innovation in the public sector to tackle current economic and social challenges. This rather prevalent normative assumption and the equation of innovation and improvement has 
been contested by some researchers (e.g., Brown \& Osborne, 2013; Hartley, 2005, 2011, 2014; Osborne \& Brown, 2011; Torfing, 2019); these researchers argue that although the innovation process may be considered essential for improving public services, this does not mean that any specific innovation is positive or will lead to improvement (Osborne \& Brown, 2011). Any innovation carries a risk of failure or partial failure. Improvement can occur without innovation in continuous efforts of improvement which are based on doing things better, whereas innovation is based on doing things differently (Hartley, $2014,2011)$. This exemplifies a normative distinction in conceptualising innovation, which can be discussed in terms of either value or improvements.

Another extensive strand of public sector innovation research relevant to the normative dimension is the vast and growing literature on public value. Public value was first introduced by Moore in 1995 as a conceptual framework for managers (Benington \& Moore, 2011), seen by some researchers as associated with the affirmation of managerial ingenuity and expertise (Williams \& Shearer, 2011), for others as a way of thinking that is both postbureaucratic and postcompetitive (O'Flynn, 2007). Thus, just like public sector innovation, public value is a concept with a contested meaning. Some of this literature relates public value to innovation. Chen et al. (2020), for example, define public service innovation as 'the development and implementation of a novel idea by a public service organisation (PSO) to create or improve public value within an ecosystem' (p. 1677). Gieske et al. (2016) present a similar definition of innovation that includes the creation of public value. Public value has increasingly emerged as a term in politics and public administration literature and public sector improvement programmes (Williams \& Shearer, 2011). In this sense, public value is associated with an improvement of public services, but also with performance measurement (Moore, 2014) and attempts to conceptualise the value created by the public sector. The concept relates to normative ideas about what the public sector is and ought to be. That being said, public value is not always explicitly linked to innovation, and some research has focused only on public value without connecting it to innovation. However, when the two concepts are connected, this also has implications for the normative dimension of conceptualising public sector innovation.

Public value research has broadened its perspectives (Hartley et al., 2017) and is often portrayed today as a new paradigm associated with Networked Governance (Benington, 2011; Stoker, 2006), where public value 
management practice is based on the systems of dialogue and the exchange in networks. Here, public value is more than a summation of the individual preferences of service users: it is built collectively through deliberation involving elected and appointed government officials and key stakeholders (Stoker, 2006). Benington (2011) argues that public value can be interpreted as both safeguarding and enriching the public sphere while delivering what the public values. Hartley et al. specify 'at least three, sometimes disparate, components of public value in contemporary public management thought: the notion of public value contributing to the public sphere; the notion of public value as the addition of value through actions in an organisational or partnership setting and the heuristic framework of the strategic triangle (the public value proposition, the authorising environment and operational resources which a public manager has to align to achieve public value)' (2017, p. 671). Each of these has a different theoretical basis and addresses specific research questions. Linking them to public sector innovation also provides different perspectives regarding the normative dimensions of conceptualising. The first notion, which for example Benington (2011) represents, sees public value as providing an alternative and improved construct to explain public welfare through the contribution of the public sphere. Public value is closely linked to democratic processes and defined through democratic practices (Hartley et al., 2017). The second notion conceptualises public value as created or added through the activities of public organisations and their managers; it focuses on the added value relevant to societal outcomes. What counts as valuable is sometimes presented in terms of the normative aspirations for a 'good society'. Connecting the conceptualisations of public sector innovation to the literature on public value opens up ways of explicitly discussing —and perhaps providing a normative justification for-the value dimensions of the public sector. This implies deliberations of what the public sector is and should do and, thus, also what innovation should help develop. For example, there is an explicit link to the public sphere and the political and democratic dimensions of the public sector. When discussing how to understand value in terms of democratic processes (as a procedural justification for when something can be considered valuable or desirable) or in terms of the attempts to specify the role of management or citizens in improvement processes, this also provides a framework for the conceptualisation of innovation and what can be considered relevant public sector developments. 


\section{Concluding discussion: Questions for the future}

Based on discussions of current research on public sector innovation, the current article has identified three dimensions-an epistemological, pragmatic and normative-which can hopefully guide future reflections. The three dimensions refer to different but interrelated questions to reflect upon in relation to conceptualising innovation; these include the question of whether public sector innovation should be understood mainly as a concept for describing and understanding certain activities, which can be empirically identified in public organisations, or whether it can also be seen as a tool to guide practice. Finally, there is the normative question of whether public sector innovation should be understood as leading positive developments in the sector, which is also related to understandings of the role and political aspects of the public sector. Different suggestions for why the public sector should be innovative (if at all) also call for different conceptions because they are basically answers to different questions or challenges. Engaging with these meta-conceptual questions enables us to separate the dimensions and reflect on what the conceptualisation consists of. We can then more explicitly discuss the criteria for a 'good' or 'adequate' concept of public sector innovation.

In relation to the epistemological dimension, researchers could ask themselves whether innovation is intended as a concept for explaining, describing, predicting or interpreting. What is the role of context? Can we use the concept of innovation as a general context-independent variable? These are traditional methodological questions, but they are not always addressed explicitly in the literature on public sector innovation. These questions are interrelated with the question of why we need such a concept in the first place. Is it merely to ensure accuracy in empirical studies aiming at generalisable knowledge of the drivers and barriers of innovation? Do we wish to explain to predict? Is innovation a tangible entity, something that we can find 'out there' in a more realistic sense? Much research seems to assume this. The literature included in the current paper contains little reflection on the performative dimensions of the concept, namely how it not only describes or explains, but also contributes to constituting the phenomenon of innovation in the public sector. What are the implications of introducing this particular concept in this context, and what kinds of practices and discourses does it constitute? These critical perspectives seem largely absent from the field of public sector innovation. A more detailed analysis of the implications of conceptualising the public sector in certain ways is needed. Thus, it is not only a question of what 
the assumed empirical phenomenon is, but also of how the concept constitutes reality (in a more social constructivist or critical manner).

The next question is what the practical implications of our knowledge are and whether it has practical significance in how we conceptualise or distinguish innovation from other phenomena. If the answer to why we need a concept of public sector innovation is that it strengthens the public sector's problemsolving capacity, then we need to be explicit about how this practical dimension relates to the way we conceptualise. This view points to more practical knowledge about how innovation relates to and can help solve specific problems, such as wicked problems. Some of the research linking public sector innovation to collaboration, networked governance and partnerships addresses innovation in this way. Some studies explicitly show interest in innovation as something to use, not just know about, such as a management tool and for managing specific types of discontinuous change processes. However, is innovation just assumed to be valuable, or should the concept also indicate when it is valuable or not? Do we need the concept to understand or control the public sector or to strengthen it as a democratic institution? These questions indicate the interconnection between the epistemological, pragmatic and normative dimensions of conceptualising.

The normative dimension relates to the distinction between innovation and improvement or value creation. As we have seen, some scholars explicitly include improvement in the definition of innovation, while others just assume that it is desirable and inherently good. Others again argue that innovation does not always lead to improvement and that the two should be distinguished because what counts as improvements can be contested and depend on positioning and perspectives. The normative dimension of the concept can be viewed in relation to whether individual innovations imply an improvement and whether innovation research should formulate the criteria for improvement, thereby becoming explicitly normative. The dimension can also relate more generally to the main role of the public sector and whether innovation should strengthen it as a public sector (e.g., with a specific obligation to ensure justice, rights and citizenship; Eriksen, 1999; Langergaard, 2011). This relates to the political and value dimensions of the concept, and when innovation is conceptualised as leading to value creation, these normative dimensions must be defined. This is also a normative question of how we should understand value (justify what is valuable) in a public sector context. Engaging with such 
questions includes concerns about the democratic role of the sector, how innovation contributes to develop and/or transform it into a more public sector and how this is understood. This can be defined in a procedural way, where some strands in public value research stress that the public interest or common good is constituted and defined through democratic procedures (Benington, 2011; Hartley et al., 2017).

All three dimensions are relevant to reflect upon when navigating the field of public sector innovation. As mentioned in the introduction, there is no agreement on what counts as innovatory and how innovation should be conceptualised, and we cannot just assume that we know what public sector innovation means. Innovation has become a powerful organising metaphor with implications for practice and, thus, also political implications (because the sector is democratically governed). Neglecting the normative dimension involves the risk of the depoliticisation of public sector innovation as a concept and an organisational and political phenomenon. The political and democratic context of the public sector calls for conscious ways of conceptualising that avoid the pitfalls of the unintentional depoliticisation of the sector and its services. 


\section{References}

Agger, A., Damgaard, B., Krogh A. H., \& Sørensen, E. (2015). Introduction. In A. Agger, B. Damgaard, A. H. Krogh \& E. Sørensen (Eds.), Collaborative governance and public innovation in Northern Europe (pp. 3-22). Bentham ebooks. https://doi.org/10.2174/9781681080130115010004

Albury, D. (2005). Fostering innovation in public services. Public Money and Management, 25(1), 51-56.

Audi, R. (1998). Epistemology: A contemporary introduction to the theory of knowledge. Routledge.

Bason, C. (2010). Leading public sector innovation: Co-creating for a better society. Policy Press. https://doi.org/10.2307/j.ctt9qgnsd

Becheikh, N., Halilem, N., Jbilou, J., Mosconi, E., Hammami, H., \& Landry, R. (2007). Conceptualization and determinants of innovation in the public sector: A systematic review [Paper presented]. 14th Reser International Conference on service Competitiveness and Cohesion, Tampera, Finland, September 2007.

Benington, J. (2011). From private choice to public value. In J. Benington \& M. Moore (Eds.), Public value: Theory and practice (pp. 31-51). Palgrave Macmillan. https://doi.org/10.1007/978-0-230-36431-8_2

Benington, J., \& Moore, M. (2011). Public value in complex and changing times. In J. Benington \& M. Moore (Eds.), Public value: Theory and practice (pp. 1-30). Palgrave Macmillan. https://doi.org/10.1007/978-0-230-36431-8_1

Bekkers, V., Tummers, L., \& Voorberg, W. (2013). From public innovation to social innovation in the public sector: A literature review of relevant drivers and barriers [Paper presented]. EGPA 2013 Conference, Edinburgh, Scotland.

Bommert, B. (2010). Collaborative innovation in the public sector. International Public Management Review, 11(1), 15-33.

Brown, L., \& Osborne, S. (2013). Risk and innovation. Public Management Review, 15(2), 186-208. https://doi.org/10.1080/14719037.2012.707681

Buchheim, L., Krieger, A., \& Arndt, S. (2020). Innovation types in public sector organizations: A systematic review of the literature. Management Review Quarterly, 70, 509-533. https://doi.org/10.1007/s11301-019-00174-5

Callon, M. (2010). Performativity, misfires and politics. Journal of Cultural Economy, 3(2), 163-169. https://doi.org/10.1080/17530350.2010.494119

Chen, J., Walker, R., \& Sawhney, M. (2020). Public service innovation: A typology. Public Management Review, 22(11), 1674-1692. https://doi.org/10.1080/14719037.2019.1645874

Cinar, E., Trott, P., \& Simms, C. (2019). A systematic review of barriers to public sector innovation process. Public Management Review, 21(1), 264-290. https://doi.org/10.1080/14719037.2018.1473477

Copp, D. (2001). Morality, normativity and society. Oxford University Press. 
Crosby, B. C., 't Hart, P., \& Torfing, J. (2017). Public value creation through collaborative innovation. Public Management Review, 19(5), 655-669. https://doi.org/10.1080/14719037.2016.1192165

Damanpour, F., \& Schneider, M. (2009). Characteristics of innovation and innovation adoption in public organizations: Assessing the role of managers. Journal of Public Administration Research and Theory, 19(3), 495-522. https://doi.org/10.1093/jopart/mun021

Dancy, J. (2002). Editor's introduction. In J. Dancy (Ed.), Normativity (pp. vii-xv). Blackwell Publishers.

De Vries, H., Bekkers, V., \& Tummers, L. (2016). Innovation in the public sector: A systematic review and future research agenda. Public Administration, 94(1), 146-166. https://doi.org/10.1111/padm.12209

Du Gay, P., \& Vikkelsø, S. (2017). For formal organization: The past in the present and future of organization theory. Oxford University Press. https://doi.org/10.1093/acprof:oso/9780198705123.001.0001

Eriksen, E. O. (1999). Kommunikativ ledelse - om styring av offentlige organisasjoner. Fagbokforlaget.

Etymonline.com. (n.d.). Concept. In Etymonline.com. https://www.etymonline.com/search?q=concept

Fuglsang, L., \& Rønning, R. (2014). Introduction: Framing innovation in public service sectors: A contextual approach. In L. Fuglsang, R. Rønning, \& B. Enquist (Eds.), Framing innovation in public sector services (pp. 1-17). Routledge. https://doi.org/10.4324/9781315885612

Fuglsang, L., \& Sørensen, F. (2011). The balance between bricolage and innovation: Management dilemmas in sustainable public innovation. The Service Industries Journal, 31(4), 581-595. https://doi.org/10.1080/02642069.2010.504302

Gieske, H., van Buuren, A., \& Bekkers, V. (2016). Conceptualizing public innovative capacity: A framework for assessment. The Innovation Journal, 21(1), 1-25.

Godin, B. (2008). Innovation: The history of a category. Project on the Intellectual History of Innovation, Working Paper No. 1. INRS.

Godin, B. (2015). Innovation contested: The idea of innovation over the centuries. Routledge. https://doi.org/10.4324/9781315855608

Goodman, R. B. (1995). Introduction. In R. B. Goodman (Ed.), Pragmatism: A contemporary reader (pp. 1-21). Routledge. https://doi.org/10.4324/9781003061502-1

Gow, J. I. (2014). Public sector innovation theory revisited. The Innovation Journal, 19(2), 1-22.

Haag, S. (2003). Klassisk og senere pragmatisme. In P. Lübke (Ed.), Engelsk og Amerikansk Filosofi: Videnskab og Sprog (pp. 529-543). Politikens Forlag.

Hansen, A. V., \& Madsen, S. (2019). Theorizing in organization studies - Insights from key thinkers. Edward Elgar. 
Hartley, J. (2005). Innovation in governance and public services: Past and present. Public Money and Management, 25(1), 27-34.

Hartley, J. (2011). Public value through innovation and improvement. In J. Bennington \& M. H. Moore (Eds.), Public value: Theory and practice (pp. 171-184).

Palgrave Macmillan. https://doi.org/10.1007/978-0-230-36431-8_10

Hartley, J. (2014). New development: Eight and a half propositions to stimulate frugal innovation. Public Money and Management, 34(3), 227-232.

https://doi.org/10.1080/09540962.2014.908034

Hartley, J. (2016). Organisational and governance aspects of diffusing public innovation. In J. Torfing \& P. Triantafillou (Eds.), Enhancing public innovation by transforming public governance (pp. 95-113). Cambridge University Press. https://doi.org/10.1017/CBO9781316105337.005

Hartley, J., Sørensen, E., \& Torfing, J. (2013). Collaborative innovation: A viable alternative to market competition and organizational entrepreneurship. Public Administration Review, 73(6), 821-830. https://doi.org/10.1111/puar.12136

Hartley, J, Alford, J., Knies, E., \& Douglas, S. (2017). Towards an empirical research agenda for public value theory. Public Management Review, 19(5), 670-685. https://doi.org/10.1080/14719037.2016.1192166

Kattel, R., Cepilovs, A., Drechsler, W., Kalvet, T., Lember, V., \& Tônurist, P. (2014). Can we measure public sector innovation? A literature review. LIPSE Project Working Paper No. 2. www.lipse.org

King, C. S., \& Martinelli, A. S. (2005). Introduction - Innovations in citizen engagement and empowerment: Beyond boundaries. The Innovation Journal, 10(1), 1-8

Langergaard, L. L., Rasmussen, S. B., \& Sørensen, A. (2006). Viden, Videnskab og Virkelighed. Samfundslitteratur.

Langergaard, L. L. (2011). Innovating the 'publicness' of the public sector? A critical, philosophical discussion of public sector innovation [Doctoral thesis, Roskilde University].

Langergaard, L. L. (2019). Social innovation learning from critical social entrepreneurship studies: How are they critical and why do we need them? In S. Carney, S. Banerjee, \& L. Hulgård (Eds.), People centered social innovation: Global perspectives on an emerging paradigm (pp. 17-41). Routledge. https://doi.org/10.4324/9781351121026-2

Moltesen, J., \& Dahlerup, S. (2008). Dekoblingspolitik: Visioner og initiativer i den danske regerings innovationspolitik. Forlaget Politiske Studier.

Moore, M. H. (2005). Break-through innovations and continuous improvement: Two different models of innovative processes in the public sector. Public Money \& Management, 25(1), 43-50.

Moore, M., \& Hartley, J. (2008). Innovations in governance. Public Management Review, 10(1), 3-20. https://doi.org/10.1080/14719030701763161 
Moore, M. H. (2014). Public value accounting: Establishing the philosophical basis.

Public Administration Review, 74(4), 465-477.

https://doi.org/10.1111/puar.12198

Mulgan, G., \& Albury, D. (2003). Innovation in the public sector. Strategy Unit.

OPSI (Observatory for Public Sector Innovation) (2020). Public Sector Innovation Scan

of Denmark. Retrieved at (22.11.2021):

https://www.coi.dk/media/53245/public-sector-innovation-scan-

denmark_017.pdf

Osborne, S. P., \& Brown, L. (2011). Innovation, public policy and public service delivery in the UK: The word that would be king? Public Administration, 89(4), 13351350. https://doi.org/10.1111/j.1467-9299.2011.01932.x

O'Flynn, J. (2007). From new public management to public value: Paradigmatic change and managerial implications. The Australian Journal of Public Administration, 66(3), 353-366. https://doi.org/10.1111/j.1467-8500.2007.00545.x

Paulsen, M. (2011). Innovationsbegrebets dialektik i en uddannelseskontekst - en strid mellem forskellige innovationsforståelser. In M. Paulsen \& S. H. Klausen (Eds.), Innovation og læring - filosofiske og kritiske perspektiver (pp. 13-48). Aalborg Universitetsforlag.

Pollitt, C. (2011). Innovation in the public sector: An introductory overview. In V. Bekkers, J. Edelenbos, \& B. Steijn (Eds.), Innovation in the public sector (pp. 23-28). Palgrave Macmillan. https://doi.org/10.1057/9780230307520_2

Pollitt, C., \& Hupe, P. (2017). Talking about government: The role of magic concepts. Public Management Review, 13(5), 641-658. https://doi.org/10.1080/14719037.2010.532963

Potts, J., \& Kastelle, T. (2010). Public sector innovation research: What's next? Innovation: Management, Policy \& Practice, 12(2), 122-137. https://doi.org/10.5172/impp.12.2.122

Sannerstedt, A. (2003). Implementering - hur politiske beslut genomförs i praktiken. In B. Rothstein (Ed.), Politik som organisation: Förvaltningspolitikens grundproblem (pp. 18-48). SNS Förlag.

Schumpeter, J. A. (2008). The theory of economic development. Transaction Publishers.

Sørensen, E., \& Torfing, J. (2011a). Samarbejdsdreven innovation i den offentlige sektor. In E. Sørensen \& J. Torfing (Eds.), Samarbejdsdrevet innovation - i den offentlige sektor (pp. 19-37). Jurist- og Økonomiforbundets Forlag.

Sørensen, E., \& Torfing, J. (2011b). Enhancing collaborative innovation in the public sector. Administration and Society, 43(8), 842-868. https://doi.org/10.1177/0095399711418768

Stoker, G. (2006). Public value management: A new narrative for networked governance? American Review of Public Administration, 36(1), 41-57. https://doi.org/10.1177/0275074005282583 
Swedberg, R. (2006). Social entrepreneurship: The view of the young Schumpeter. In C. Steyaert \& D. Hjort (Eds.), Entrepreneurship as social change (pp. 21-34). Edward Elgar. https://doi.org/10.4337/9781847204424.00010

Torfing, J. (2019). Collaborative innovation in the public sector: The argument. Public Management Review, 21(1), 1-11.

https://doi.org/10.1080/14719037.2018.1430248

Williams, I., \& Shearer, H. (2011). Appraising public value: Past, present and futures. Public Administration, 89(4), 1367-1384. https://doi.org/10.1111/j.14679299.2011.01942.x 